\title{
An Outbreak of Aseptic Meningitis Due to Echovirus 30 in a High School Baseball Club-Possible Role of Severe Exercise for a High Attack Rate
}

\author{
Takeshi Hayashi ${ }^{1}$, Takamasa Shirayoshi ${ }^{1}$, Takuro Nagano ${ }^{2}$, Hiroyuki Yaoita ${ }^{2}$, Shuji Kogure ${ }^{2}$, \\ Hiroki Nariai $^{3}$, Tomo Natsumeda ${ }^{3}$, Mayumi Taniuchi ${ }^{3}$, Mitsuru Sandoh ${ }^{4}$ and Yoshitake Sato ${ }^{3}$
}

\begin{abstract}
In September 2008, an outbreak of aseptic meningitis caused by echovirus 30 occurred in Ota City, Gunma. Among the 26 people hospitalized, 17 were members of a high school baseball club. The attack rate within the club was as high as $40 \%$. The other 9 patients were either their families or close relatives of the baseball club members, indicating the outbreak was confined to a limited community. Although numerous outbreaks of echoviral meningitis have been reported worldwide, those with such a high attack rate within a limited community are rare. Severe physical exercise in a hot temperature could be associated with this high attack rate.
\end{abstract}

Key words: echovirus, enterovirus, meningitis, outbreak, transmission, attack rate

(Inter Med 48: 1767-1771, 2009)

(DOI: 10.2169/internalmedicine.48.2298)

\section{Introduction}

Viral meningitis is the most common type of meningitis $(1,2)$. Its exact annual incidence in Japan is unknown, but approximately 50,000 people per year are hospitalized in North America (3). Although etiological agents are not determined in many cases, enterovirus is the most frequent agent when identified, ranging from 30 to $83 \%(1,4)$.

Enteroviruses are single-strand RNA virus, and more than 60 serotypes are known (5). Some serotypes have strong association with meningitis, though others seldom cause it. Echovirus 30 (E30) is among them one of the most frequently identified causative agents $(2,6,7)$. There have been many reports of E30 meningitis epidemics, but most were of open community outbreaks $(3,8-21)$. The attack rate was, therefore, quite low. We found only a few reports of E30 meningitis outbreaks in limited communities, but one was of co-infection with other enteroviruses (22) and others were of a lower attack rate (23-27). In September 2008, we encountered an outbreak of E30 meningitis in a limited community. Most patients belonged to a baseball club, and about $40 \%$ of the club members needed to be hospitalized. Here, we report this outbreak and discuss the possible mechanism of this extraordinarily high attack rate.

\section{Case Report}

A 15-year-old boy with no remarkable past disease history was admitted to our hospital in early September, 2008, complaining of fever, headache, and vomiting which lasted for 4 days (patient 1 in Table 1). He belonged to a high school baseball club, and had been doing well till September 1. No close friends or relatives had febrile illness before he became sick. In spite of fever and severe headache, no consciousness disturbance or focal neurological deficits were confirmed. There also were no physiological abnormalities other than mild tachycardia presumably associated with the fever. Of note was that he showed no definite neck stiffness. Mild leukocytosis $(13,000 / \mu \mathrm{L})$ was found and the C-reactive

\footnotetext{
${ }^{1}$ Department of Neurology, Fuji Heavy Industries Health Insurance Corporation Ota General Hospital, Ota, ${ }^{2}$ Neurosurgery, Fuji Heavy Industries Health Insurance Corporation Ota General Hospital, Ota, ${ }^{3}$ Pediatrics, Fuji Heavy Industries Health Insurance Corporation Ota General Hospital, Ota and ${ }^{4}$ Pharmacy, Fuji Heavy Industries Health Insurance Corporation Ota General Hospital, Ota

Received for publication March 24, 2009; Accepted for publication June 29, 2009

Correspondence to Dr. Takeshi Hayashi, thayashi@ota-hosp.or.jp
} 
Table 1. Patients of Viral Meningitis Admitted to Our Hospital

\begin{tabular}{ccccccl}
\hline $\begin{array}{c}\text { patient } \\
\text { No. }\end{array}$ & sex & age & $\begin{array}{c}\text { onset } \\
\text { date }\end{array}$ & $\begin{array}{c}\text { admission } \\
\text { date }\end{array}$ & $\begin{array}{c}\text { discharged } \\
\text { date }\end{array}$ & \multicolumn{1}{c}{ relation with the baseball club } \\
\hline 1 & M & 15 & $9 / 2$ & $9 / 5$ & $9 / 8$ & club member, brother of patient 2 and 8 \\
2 & F & 7 & $9 / 6$ & $9 / 8$ & $9 / 11$ & sister of patient 1 and 8 \\
3 & M & 15 & $9 / 6$ & $9 / 9$ & $9 / 15$ & club member \\
4 & M & 15 & $9 / 6$ & $9 / 12$ & $9 / 15$ & club member \\
5 & M & 16 & $9 / 6$ & $9 / 12$ & $9 / 15$ & club member \\
6 & M & 16 & $9 / 7$ & $9 / 8$ & $9 / 13$ & club member \\
7 & M & 15 & $9 / 7$ & $9 / 10$ & $9 / 15$ & club member \\
8 & M & 17 & $9 / 8$ & $9 / 9$ & $9 / 13$ & brother of patient 1 and 2 \\
9 & M & 16 & $9 / 8$ & $9 / 10$ & $9 / 15$ & club member \\
10 & F & 8 & $9 / 8$ & $9 / 11$ & $9 / 13$ & cousin of patient 1,2 and 8 \\
11 & M & 15 & $9 / 8$ & $9 / 11$ & $9 / 15$ & club member \\
12 & M & 16 & $9 / 9$ & $9 / 11$ & $9 / 15$ & club member \\
13 & M & 16 & $9 / 10$ & $9 / 16$ & $9 / 20$ & club member \\
14 & M & 17 & $9 / 11$ & $9 / 11$ & $9 / 17$ & club member \\
15 & M & 16 & $9 / 12$ & $9 / 16$ & $9 / 18$ & brother of a club member \\
16 & M & 18 & $9 / 13$ & $9 / 14$ & $9 / 16$ & brother of a club member \\
17 & M & 16 & $9 / 14$ & $9 / 14$ & $9 / 18$ & classmate of patient 6 and 14 \\
18 & M & 17 & $9 / 14$ & $9 / 16$ & $9 / 20$ & classmate of patient 6 and 14 \\
19 & M & 17 & $9 / 14$ & $9 / 18$ & $9 / 21$ & club member \\
20 & F & 33 & $9 / 16$ & $9 / 17$ & $9 / 19$ & mother of a friend of patient 2 and 3 \\
21 & M & 9 & $9 / 17$ & $9 / 18$ & $9 / 24$ & brother of patient 8 \\
\hline & & & & & &
\end{tabular}

protein (CRP) level was elevated $(1.64 \mathrm{mg} / \mathrm{dL})$. As meningitis was suspected, we performed a lumbar tap study. The results of cerebrospinal fluid (CSF) analysis were as follows: initial pressure, $220 \mathrm{mmH}_{2} \mathrm{O}$; cell count, 88 cells/ $\mu \mathrm{L}(85 \%$ polymorphonuclear cells: PMN); protein, $57 \mathrm{mg} / \mathrm{dL}$; glucose, $47 \%$ of blood glucose level. No bacterial growth was confirmed in the CSF. His brain CT scanning showed no abnormal findings (not shown).

We suspected viral meningitis, but ceftriaxone sodium was intravenously given because PMN predominance in the CSF made it difficult to rule out bacterial meningitis. Fever, headache, and emesis gradually subsided, and the antibiotic was discontinued two days later because the benign clinical course further suggested viral meningitis. He became afebrile, and went home three days after admission.

On the same day when patient 1 was discharged, a 7year-old girl (patient 2 in Table 1) and a 16-year-old boy (patient 6 in Table 1) came to our hospital complaining of similar symptoms as patient 1 . Patient 2 was a sister of patient 1 , and her symptoms had started soon after those of her broher. Patient 6 was a member of the baseball club to which patient 1 belonged, and the symptoms had appeared a few days after those of patient 1 . As patient 2 and 6 showed meningeal irritation signs, they were diagnosed as meningitis. As the results of CSF study were compatible with viral meningitis, they were hospitalized and treated with nonsteroidal anti-inflammatory drugs and intravenous antiemetics. They showed a benign clinical course, and were discharged several days later (Table 1).

As shown in Table 1, many patients were admitted to our hospital under the diagnosis of viral meningitis thereafter.
More than half of the patients belonged to the baseball club. Other patients, though not a club member, had evidence of direct or indirect contact with the baseball club members who became sick. Patient 17 and 18 were classmates of patient 5 and 14. By interviewing, it became evident that their seats were close in a classroom and had shared drink bottle. Patient 20 did not seem to have contact with other patients, but her daughter showed symptoms of viral meningitis; her daughter was a close friend of patients 2 and 10, and likely caught viral meningitis of the same etiology.

Five more baseball club members were admitted to other hospitals under the diagnosis of viral meningitis. Among 43 club members, therefore, 17 people became hospitalized. According to the manager of the club, all other baseball club members who were not hospitalized also experienced headache and fever; if we consider these people as having meningitis, the attack rate increases to $100 \%$. On the other hand, no patients of viral meningitis came to our hospital in the same season after patient 21 . According to the local public health center, no cases of aseptic meningitis were reported thereafter. We can suppose that this epidemic was stamped out promptly, without extending to an open community outbreak.

Symptoms and signs as well as the results of laboratory data of the patients admitted to our hospital are summarized in Table 2. As the medical record or CSF data were insufficient, those of patients who admitted to other hospitals were not included. The results of data analysis were essentially compatible with previous reports, which will be discussed later. Several patients underwent electroencephalography and brain imaging studies, but no patients showed abnormal 
Table 2. Symptoms, Signs and Laboratory Data of the Hospitalized Patients

\begin{tabular}{lrlr}
\hline symptoms & \multicolumn{3}{c}{ CSF } \\
headache & $100 \%$ & initial pressure $(\mathrm{mmH} 2 \mathrm{O})$ & $216.4 \pm 43.6$ \\
fever & $100 \%$ & cells $/ \mu \mathrm{L})$ & $108.9 \pm 114.0$ \\
emesis & $90.5 \%$ & percentage of PMN $(\%)$ & $59.7 \pm 28.9$ \\
diarrhea & $9.5 \%$ & protein $(\mathrm{mg} / \mathrm{dL})$ & $33.8 \pm 16.2$ \\
throat pain & $23.8 \%$ & glucose $(\%$ of blood glucose) & $55.5 \pm 7.8$ \\
& & & \\
signs & & blood & $10205 \pm 2157$ \\
Jolt accentuation & $87.5 \%$ & WBC $(/ \mu \mathrm{L})$ & $1.65 \pm 1.72$ \\
neck stiffness & $60.0 \%$ & CRP $(\mathrm{mg} / \mathrm{dL})$ & \\
Kernig sign & $23.5 \%$ & & \\
\hline
\end{tabular}

$\mathrm{CRP}=\mathrm{C}$ reactive protein; $\mathrm{CSF}=$ cerebrospinal fluid; $\mathrm{PMN}=$ polymorphonuclear cells; WBC=white blood cell

Table 3. Detection of E30 RNA or Neutralizing Antibody against E30

\begin{tabular}{ccc}
\hline $\begin{array}{c}\text { Ptient No. in } \\
\text { Table } 1\end{array}$ & CSF & $\begin{array}{c}\text { pharyngeal } \\
\text { swab }\end{array}$ \\
\hline 2 & + & NE \\
3 & + & NE \\
4 & NE & + \\
6 & + & NE \\
7 & + & + \\
8 & + & NE \\
9 & + & + \\
10 & + & + \\
11 & + & + \\
12 & + & + \\
13 & - & NE \\
14 & + & + \\
17 & - & NE \\
\hline CSF=cerebrospinal fluid; E30=echovirus
\end{tabular}

30; $\mathrm{NE}=$ not examined

findings (not shown). We sent CSF and/or pharyngeal swab of several patients to Gunma prefectural infection control center to identify the causative agent. In the prefectural infection control center, serotype-specific viral RNA and antibody were investigated. As summarized in Table 3, clinical samples of 11 among 13 patients revealed evidence of E30 infection. As no other causative agents were identified, we supposed that this outbreak was caused merely by E30.

\section{Discussion}

Isolation of virus in a cell culture was the traditional method to identify the causative agent of viral meningitis, but it usually has low sensitivity and therefore was replaced by indirect methods such as nucleic acid or serotype-specific antibody detection (28). As serotype-specific nucleic acid and/or antibody were confirmed from many clinical samples, we can consider that this outbreak was caused by E30. There were some reports of aseptic meningitis outbreaks with simultaneous involvement of plural enterovirus sero- types $(22,29)$, but the cluster reported is likely due only to E30; the serotype-specific diagnostic reliability of RNA is quite high (28), and absence of other serotypes in 19 samples from 13 patients (Table 3) excluded the possibility of co-infection.

E30 is one of the most common causative agents of aseptic meningitis (30). In the United States, it accounted for $8.2 \%$ of aseptic meningitis from 1970 to 2001 (2). It sometimes causes epidemics of meningitis, some of which involves a whole nation $(3,8,9)$, a province or city (10-21), or a limited community (22-27). It is transmitted person to person by the oral-fecal route, but contamination in open water plays an important role in open community epidemics (20). As for the outbreak reported here, direct person to person transmission was the sole mode of propagation; we could verify the fact of direct contact in all cases (Table 1).

Previous records of E30 meningitis demonstrate that almost all cases showed headache and fever $(4,31)$, followed by vomiting $(60-90 \%)(4,15,31)$, diarrhea $(11 \%)(4,14)$, and rash $(3-9 \%)(4,14,31)$. One report from China (32) showed that more than half of the patients developed encephalitis, but all other case reports demonstrated a good outcome. The present cases showed similar results, but no patients showed skin lesions (Table 2). About $24 \%$ of patients complained of throat pain, which was again compatible with previous reports $(4,14)$. Despite that meningeal irritation signs seem to be the prerequisite for the diagnosis of meningitis, the present cases revealed that not all patients showed all meningeal signs (Table 2). Previous reports (4, 31) also showed that neck stiffness was confirmed only in $70 \%$ cases, and therefore, we should not exclude meningitis even when meningeal irritation signs are absent. Among the three meningeal irritation signs investigated here, Jolt accentuation signs showed the highest sensitivity (Table 2), which is compatible with a previous report (33). When a patient with a possible diagnosis of meningitis is encountered, the Jolt accentuation test is of great importance.

Although PMN predominance in CSF (Table 2) seems atypical for viral meningitis, previous reports also showed similar result $(4,14,21,30)$. The present cases further suggested that PMN predominance in CSF does not necessarily 
mean bacterial meningitis. The number of cells and protein level in CSF tended to be lower in enterovirus meningitis than in herpes virus meningitis (31). In our cases, however, they greatly differed from case to case (cell count, 0 to 370/ $\mu \mathrm{L}$; protein level, 10 to $77 \mathrm{mg} / \mathrm{dL}$ ), which made it difficult to speculate causative agents only by CSF pleocytosis or protein increase. In addition, the degree of inflammation in CSF did not indicate the severity of disease.

Many people remain asymptomatic when infected by enterovirus $(7,34)$. Even if symptomatic infection occurs, enterovirus usually causes only mild febrile illness; less than 5 $\%$ of people with symptomatic enterovirus infection develop meningitis $(34,35)$. Therefore, most outbreaks of enterovirus meningitis involve relatively small number of people compared to those with possible virus exposure. It is difficult to calculate the attack rate in open community outbreaks, but it is quite low. In an outbreak of E30 meningitis in southern Taiwan, for example, 38 people showed symptoms of meningitis (4). In an outbreak of northwest England also, only 38 people contracted meningitis. Two-hundred fifteen people suffered from meninigitis in Kassel and neighboring countries in 2001, but the number of patients was very small when we take the total population within the area into account. As transmission occurs in a different way from that of limited community outbreaks, the viral load for each people might be lower in open community epidemics. When we discuss attack rate of meningitis epidemics, therefore, we need to distinguish limited community outbreaks from opencommunity ones.

Among the 43 members of the baseball club related to our case, 12 people were admitted to our hospital, 5 people to other hospitals, and all other people showed fever and headache even though they did not visit hospitals. When we define the attack as having fever and headache, the attack rate of meningitis within the baseball club reached $100 \%$. When we count the hospitalized patients only, the attack rate was $40 \%$. This is quite high when compared to previous reports of limited community E30 meningitis outbreaks. Faustini et al. reported a cluster of E30 meningitis among students who swam in a school pool, but the attack rate was $11 \%$ (27). Child-care centers sometimes became the place of outbreaks, but the attack rate ranged from 3 to $13 \%$ (23-25, 29). Only $24 \%$ of people with serological evidence of recent E30 infection showed symptoms in one study (23). A report with the highest attack rate we found was an outbreak within travelers to Mexico; $88 \%$ people showed fever and emesis, and $50 \%$ became hospitalized (22). However, this outbreak was brought about not only by E30 but also by other enteroviruses such as coxsackievirus A1 and A5. When we consider the outbreak caused by E30 only, our case had an extraordinarily high attack rate.

The reason for this high attack rate is not simple. The amount of virus each patient was exposed to might have been so large so as to cause clinically evident symptoms. However, the relation of virus load and symptom appearance has not been established in viral meningitis; virus replicate in host cells promptly, and whether the pathogen cause disease or be eliminated depends not only on virus load. After entering the host, enterovirus initially replicates in the oropharynx. The best temperature for enterovirus to replicate is $37^{\circ} \mathrm{C}$, and condition with lower temperature is unsuitable to cause viremia (5). This may be one of the reasons enterovirus meningitis is prevalent in hot seasons. Even if the temperature is not sufficiently high, the condition may become good for enterovirus when the host exercises and body temperature rises. In our cases, club members undertook physically severe training, and this might have played some roles in the evolvement of meningitis. Indeed, the previous report also revealed that the time spent for swimming correlated with the occurrence of clinically apparent meningitis (20, 22). In poliomyelitis also, which is caused by one of the enteroviruses, hard physical exercise often preceded establishment of paresis (36). Moreover, experimental data also demonstrates that exercise in the early phase of enterovirus infection makes the disease severe. In the animal model of murine poliomyelitis, the degree of exercise correlated with the severity of paresis (37). Cardiac muscle damage caused by coxsackie virus, that is one of the enteroviruses, that was augmented by exercise (38). Not only virus replication but also immunomodulation might be implicated in this exercise-induced exacerbation $(39,40)$; the number of $\mathrm{T}$ lymphocytes in the damaged tissue was changed by exercise $(41,42)$. It is thus believed that severe exercise makes the disease more severe in enteroviruses infection (6). The high attack rate of viral meningitis outbreak in Ota City, Gunma, might be brought about because of the hard training in the baseball club in hot temperature.

\section{References}

1. Tyler KL, Martin JB. Infectious Diseases of the Central Nervous System. F.A. Davis Company, Philadelphia, 1993: 3-22.

2. CDC. Outbreaks of aseptic meningitis associated with enteroviruses 9 and 30 and preliminary surveillance reports on enterovirus activity一United States, 2003. MMWR 52: 761-764, 2003.

3. Wang JR, Tsai HP, Huang SW, Kuo PH, Kiang D, Liu CC. Laboratory diagnosis and genetic analysis of an echovirus 30associated outbreak of aseptic meningitis in Taiwan in 2001. J Clin Microbiol 40: 4439-4444, 2002.

4. Kao CH, Lee SS, Liu YC, et al. Outbreak of aseptic meningitis among adults in southern Taiwan. J Microbiol Immunol Infect 36: 192-196, 2003.

5. Rosenthal KS. Picornavirus. In: Medical Microbiology. 2nd ed. Murray PR, Kobayashi GS, Pfaller MA, Rosenthal KS, Eds. Mosby, St. Louis, 1990: 607-619.

6. Modlin JF. Enterovirus infections. In: Cecil Medicine. 23rd ed. Goldman L, Ausiello D, Eds. Elsevier, Philadelphia, 2008: 25142519.

7. Tseng FC, Huang HC, Chi CY, et al. Epidemiological survey of enterovirus infections occurring in Taiwan between 2000 and 
2005: analysis of sentinel physician surveillance data. J Med Virol 79: 1850-1860, 2007.

8. Cernescu C, Târdei G, Ruță S, Bleotu C, Alexiu I, Jucu V. An outbreak of aseptic meningitis due to ECHO 30 virus in Romania during the 1999 summer. Rom J Virol 50: 99-106, 1999.

9. Yoshida H, Hong Z, Yoneyama $\mathrm{T}$, et al. Phylogenic analysis of echovirus type 30 isolated from a large epidemic of aseptic meningitis in Japan during 1997-1998. Jpn J Infect Dis 52: 160-163, 1999.

10. Zhao YN, Jiang QW, Jiang RJ, Chen L, Perlin DS. Echovirus 30, Jiangsu Province, China. Emerg Infect Dis 11: 562-567, 2005.

11. Brunel D, Lévêque N, Jacques J, Renois F, Motte J, Andréoletti L. Clinical and virological features of an aseptic meningitis outbreak in north-eastern France, 2005. J Clin Virol 42: 225-228, 2008.

12. Takeda $R$, Nemoto $K$, Matsumoto A, Sato M, Hashimoto K, Hosoya M. Epidemiological and virological study of aseptic meningitis in children caused by echovirus type 30 in Fukushima in 2004. Kansenshogaku Zasshi 82: 177-181, 2008 (in Japanese, Abstract in English).

13. Richter J, Koptides D, Tryfonos C, Christodoulou C. Molecular typing of enteroviruses associated with viral meningitis in Cyprus, 2000-2002. J Med Microbiol 55: 1035-1041, 2006.

14. Bernit E, de Lamballerie $X$, Zandotti $C$, et al. Prospective investigation of a large outbreak of meningitis due to echovirus 30 during summer 2000 in marseilles, france. Medicine (Baltimore) 83: 245-253, 2004.

15. Gosbell I, Robinson D, Chant K, Crone S. Outbreak of echovirus 30 meningitis in Wingecarribee Shire, New South Wales. Commun Dis Intell 24: 121-124, 2000.

16. Chambon M, Bailly JL, Béguet A, et al. An outbreak due to echovirus type 30 in a neonatal unit in France in 1997: usefulness of PCR diagnosis. J Hosp Infect 43: 63-68, 1999.

17. Sato T. Outbreak of aseptic meningitis in Iwamizawa, 1997, caused by echovirus 30. Kansenshogaku Zasshi 72: 747-752, 1998 (in Japanese, Abstract in English).

18. Miwa C, Sawatari S. Epidemic of aseptic meningitis with echovirus type 30 in Gifu prefecture. Kansenshogaku Zasshi 67: 10681075, 1993 (in Japanese, Abstract in English).

19. Ozkaya E, Hizel K, Uysal G, Akman S, Terzioglu S, Kuyucu N. An outbreak of aseptic meningitis due to echovirus type 30 in two cities of Turkey. Eur J Epidemiol 18: 823-826, 2003.

20. Hauri AM, Schimmelpfennig M, Walter-Domes M, et al. An outbreak of viral meningitis associated with a public swimming pond. Epidemiol Infect 133: 291-298, 2005.

21. Carrol ED, Beadsworth MB, Jenkins N, et al. Clinical and diagnostic findings of an echovirus meningitis outbreak in the north west of England. Postgrad Med J 82: 60-64, 2006.

22. Begier EM, Oberste MS, Landry ML, et al. An outbreak of concurrent echovirus 30 and coxsackievirus A1 infections associated with sea swimming among a group of travelers to Mexico. Clin Infect Dis 47: 616-623, 2008.

23. Mohle-Boetani JC, Matkin C, Pallansch M, et al. Viral meningitis in child care center staff and parents: an outbreak of echovirus 30 infections. Public Health Rep 114: 249-256, 1999.

24. Akiyoshi K, Nakagawa N, Suga T. An outbreak of aseptic meningitis in a nursery school caused by echovirus type 30 in Kobe, Ja- pan. Jpn J Infect Dis 60: 66-68, 2007.

25. Vieth UC, Kunzelmann M, Diedrich S, et al. An echovirus 30 outbreak with a high meningitis attack rate among children and household members at four day-care centers. Eur J Epidemiol 15: 655-658, 1999.

26. Helfand RF, Khan AS, Pallansch MA, et al. Echovirus 30 infection and aseptic meningitis in parents of children attending a child care center. J Infect Dis 169: 1133-1137, 1994.

27. Faustini A, Fano V, Muscillo M, et al. An outbreak of aseptic meningitis due to echovirus 30 associated with attending school and swimming in pools. Int J Infect Dis 10: 291-297, 2006.

28. Cinque P, Bossolasco S, Lundkvist A. Molecular analysis of cerebrospinal fluid in viral diseases of the central nervous system. $\mathrm{J}$ Clin Virol 26: 1-28, 2003.

29. Dumaidi K, Frantzidou F, Papa A, Diza E, Antoniadis A. Enterovirus meningitis in Greece from 2003-2005: diagnosis, CSF laboratory findings, and clinical manifestations. J Clin Lab Anal 20: $177-183,2006$.

30. Lee BE, Davies HE. Aseptic meningitis. Curr Opin Infect Dis 20 : 272-277, 2007.

31. Ihekwaba UK, Kudesia G, McKendrick MW. Clinical features of viral meningitis in adults: significant differences in cerebrospinal fluid findings among herpes simplex virus, varicella zoster virus, and enterovirus infections. Clin Infect Dis 47: 783-789, 2008.

32. Wang DM, Zhao GC, Zhuang SM, Zhang YC. An epidemic of encephalitis and meningoencephalitis in children caused by echovirus type 30 in Shanghai. Chin Med J (Engl) 106: 767-769, 1993.

33. Uchihara $T$, Tsukagoshi $H$. Jolt accentuation of headache: the most sensitive sign of CSF pleocytosis. Headache 31: 167-171, 1991.

34. Rotbart HA. Viral meningitis. Semin Neurol 20: 277-292, 2000.

35. Rotbart HA. Enteroviral infections of the central nervous system. Clin Infect Dis 20: 971-981, 1995.

36. Horstmann DM. Acute poliomyelitis relation of physical activity at the time of onset to the course of the disease. J Am Med Ass 142: 236-241, 1950.

37. Rosenbaum HE, Harford CG. Effect of fatigue on susceptibility of mice to poliomyelitis. Proc Soc Exp Biol Med 83: 678-681, 1953.

38. Gatmaitan BG, Chason JL, Lerner AM. Augmentation of the virulence of murine coxsackie-virus B-3 myocardiopathy by exercise. J Exp Med 131: 1121-1136, 1970.

39. Cabinian AE, Kiel RJ, Smith F, Ho KL, Khatib R, Reyes MP. Modification of exercise-aggravated coxsackievirus B3 murine myocarditis by $\mathrm{T}$ lymphocyte suppression in an inbred model. $\mathrm{J}$ Lab Clin Med 115: 454-462, 1990.

40. Kiel RJ, Smith FE, Chason J, Khatib R, Reyes MP. Coxsackievirus $\mathrm{B} 3$ myocarditis in $\mathrm{C} 3 \mathrm{H} / \mathrm{HeJ}$ mice: description of an inbred model and the effect of exercise on virulence. Eur J Epidemiol 5: 348-350, 1989.

41. Fohlman J, Friman G, Ilback NG, Akesson A, Huber S. A qualitative and quantitative method for in situ characterization of the inflammatory response in experimental myocarditis. APMIS 98: 559-567, 1990.

42. Ilback NG, Fohlman J, Friman G. Exercise in coxsackie B3 myocarditis: effects on heart lymphocyte subpopulation and the inflammatory reaction. Am Heart J 117: 1298-1302, 1989.

(C) 2009 The Japanese Society of Internal Medicine

http://www.naika.or.jp/imindex.html 